\title{
Optimization of Crude Papaya (Carica papaya) Protease in Soft-Unripened Cheese Preparation ${\text { BUNTY MASKE }{ }^{1 *} \text {, NABINDRA KUMAR SHRESTHA }}^{1}$
}

\author{
${ }^{1}$ Central Department of Food Technology, Tribhuvan University, Dharan, Nepal
}

\begin{abstract}
The use of plant protease instead of animal rennet for producing cheese is mainly targeted to the Lacto-vegetarian consumers and religion based ecological markets. In this context, the present investigation was carried out in order to utilize the milk clotting enzyme from papaya (Carica papaya). A numerical optimization study revealed that maximum milk clotting activity was achieved at $\mathrm{pH} 6.5$, temperature $70^{\circ} \mathrm{C}$ and enzyme concentration $1 \mathrm{~g} / 1000 \mathrm{ml}$ milk using papaya protease as a coagulant. Protein and calcium content showed non-significant $(p>0.05)$ difference among the cheeses made using rennet and papaya protease. However, significantly $(p<0.05)$ higher level of ash and lower level of fat and acidity were observed in the cheese prepared by papaya protease compared to rennet cheese. The papaya protease cheese had significantly better spreadability, while other sensory properties were similar to the rennet cheese except for the slightly bitter taste. The results revealed that the papaya latex as a source of crude papaya protease may have potential application to manufacture soft-unripened cheese and further could be utilized as a milk coagulant in cheese making.
\end{abstract}

Keywords: Milk clotting, Papaya latex, Papaya protease, Soft-Unripened cheese

\section{Introduction}

Cheese is a fermented solid dairy product, which has a range of flavors and is manufactured worldwide. It is produced by clotting milk (whole or skimmed milk, partial or whole milk protein, buttermilk or combination thereof) with the aid of calf rennet (chymosin), microbial or vegetable rennet and partially draining the whey (Hickey, 2017). Calf rennet has been widely employed as a milkcoagulating agent from antiquity (Jacob et al., 2011). However, the increase in cheese production, coupled with a diminishing supply of natural animal rennet, is responsible for increases in the demand for alternative milk-coagulating sources (Chazzara et al., 2007). The increasingly higher prices of calf rennet, as well as ethical concerns associated with the production of such enzymes for general cheese making, have led to systematic investigations on the possibility and suitability of their substitution by other enzymes of microbial and plant origin (Jacob et al., 2011). Due to a number of factors such as vegetarianism and religious beliefs, attention is being turned to the use of microbial and plant coagulants (Chazzara et al., 2007). One of the benefits of using plant instead of animal proteases, such as rennet or genetically modified organism (GMO)/living modified organism (LMO)-derived enzymes is that the rich source of bioactive molecules in plants makes them a source for biotechnological applications (Gupta et al., 2015).

Several researches have been directed towards discovering a milk clotting enzyme of plant origin which would satisfactorily replace calf rennet in cheese manufacture (Duarte et al., 2009). Certain plants that have been reported to yield promising rennet activity are cardoon (Cynara cardunculus) (García et al., 2014); kiwifruit (Actinidia deliciosa) (Grozdanovic et al., 2013); sodom apple (Calotropis procera) (Freitas et al., 2016); ginger (Zingiber officinale) (Hashim et al., 2011); melon (Cucumis melo) (Mazorra-Manzano et al., 2013); moringa (Moringa oleifera) (Pontual et al., 2012), papaya (Carica papaya) (Derso \& Dagnew, 2019), and pineapple (Ananas comosus) (Bhagavathy et al., 2019). The use of these plant proteases as milk coagulants is very interesting since they are natural enzymes and can be used for producing cheeses aimed at Lacto-vegetarian consumers and ecological markets (Shah et al., 2014). Papain is a cysteine hydrolase that is stable and active under a wide range of conditions even at elevated temperatures. The papain is a natural proteolytic enzyme that is extracted from the leaf latex, the stem and the unripe papaya fruits (Amri \& Mamboya, 2012). The Carica papaya latex is a rich source of four cysteine endopeptidases including papain, chymopapain, glycyl endopeptidase, and caricain. The papaya latex can successfully be used as a coagulating agent in cottage cheese (Rana et al., 2017b). The cheese produced by using papain as a coagulant is Dangke, and it originates from Enrekang, a regency of the South Sulawesi province of Indonesia (Prasetyo et al., 2015).

Most of the plant coagulants cause excessive proteolysis and result in lower cheese yield and defects in texture and flavour (Ben Amira et al., 2017). Therefore, the present work was based on the optimization of the papaya protease utilization in the preparation of soft-unripened cheese.

\section{Materials and methods Materials}

Raw cow milk of local breed was obtained from Phushre $\left(26.8406^{\circ} \mathrm{N}, 87.2914^{\circ} \mathrm{E}\right)$, Dharan-13. Rennet (CHYMAX ${ }^{\circledR}$ Powder Extra NB) was purchased from Trishul Traders, Kathmandu. Its activity was labelled as 2235 IMCU/g and recommended usage was labelled as 30-60 IMCU/L milk. Commercial papain was purchased from Merck, India. "Papain from papaya latex" crude powder's activity was labelled as $1.5-10$ units $/ \mathrm{mg}$ solid. The latex of papaya (Carica papaya) was collected from Mangalbare $\left(26.8187^{\circ} \mathrm{N}, 87.2641^{\circ} \mathrm{E}\right)$, Dharan-11. Papaya selected 
were totally green (stage 0), small to medium sized, oval in shape. The altitude it was grown is $300-350 \mathrm{~m}$ from sea level. Trichloroacetic acid, sodium acetate, potassium phosphate and Folin-Ciocalteu reagent were purchased from Merck, India while L-tyrosine and casein were from HiMedia, India.

\section{Methods}

\section{Extraction and drying of crude papaya latex}

The latex was extracted by several longitudinal incisions with a stainless-steel blade on the unripe fruits (1-monthold) using protocol given by Nitsawang et al. (2006). This latex was allowed to run down from the fruit and drip in plastic containers. The papaya latex was dried at $40^{\circ} \mathrm{C}$ in tray drier for $2 \mathrm{~h}$ and then stored in the freezer at $-20^{\circ} \mathrm{C}$ (Puig et al., 2008).

\section{Determination of milk clotting activity (MCA)}

The milk clotting activity was determined following the procedure described by the International Dairy Federation (IDF, 2007). One unit of MCA was defined as the amount of enzyme that clots $10 \mathrm{ml}$ of reconstituted skimmed milk powder within $40 \mathrm{~min}$ at $37^{\circ} \mathrm{C}$ (Equation i) (Berridge, 1952).

$$
\operatorname{MCA}(\mathrm{U} / \mathrm{ml})=(2400 / \mathrm{T}) \times(\mathrm{S} / \mathrm{E})
$$

where, $\mathrm{T}=$ time necessary for the micellar formation (seconds); $\mathrm{S}=$ volume of the milk $(\mathrm{ml}) ; \mathrm{E}=$ volume of the enzyme (ml).

\section{Experimental Design}

The experimental design, data analysis and model building were performed by response surface methodology (RSM) using "Design Expert" software (Version 12.0.3, Stat-Ease Inc., USA). The soft-unripened cheese without added rennet was prepared with variations in: (a) $\mathrm{pH}$ of milk and (b) temperature of milk during papain addition, and (c) enzyme concentration used as shown in Table 1.

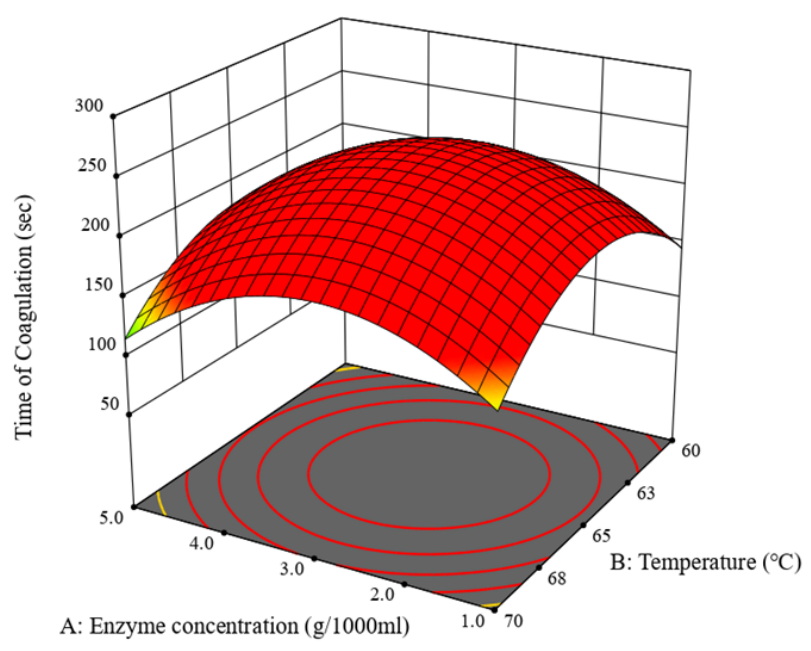

Figure 1 Response surface plot for TOC as a function of temperature of milk and enzyme concentration at $\mathrm{pH} 6.5$.
According to Mahajan and Badgujar (2010), the optimal temperature and $\mathrm{pH}$ range for papain is $60-70^{\circ} \mathrm{C}$ and $6-7$, respectively. A three-level, three-factor central composite rotatable design (CCRD) was employed (Table 2).

Table 1

Different conditions for optimization.

\begin{tabular}{lcc}
\hline Name & Goal & Range \\
\hline $\begin{array}{l}\text { Enzyme } \\
\text { concentration }\end{array}$ & To be minimized & $\begin{array}{c}1-5 \mathrm{~g} / 1000 \mathrm{ml} \\
\text { milk }\end{array}$ \\
$\begin{array}{l}\text { Temperature } \\
\text { of milk }\end{array}$ & To be in range & $60-70^{\circ} \mathrm{C}$ \\
pH of milk & Target $=6.5$ & $6-7$ \\
$\begin{array}{l}\text { Time of } \\
\text { coagulation } \\
\text { (TOC) }\end{array}$ & To be minimized & To be determined \\
$\begin{array}{l}\text { Milk clotting } \\
\text { activity } \\
\text { (MCA) }\end{array}$ & To be maximized & To be determined \\
\hline
\end{tabular}

The response variables were time of coagulation (TOC) and milk clotting activity (MCA) of the plant enzyme. The responses $\mathrm{TOC}$ and $\mathrm{MCA}$ for different experimental combinations were related to the coded variables $(\mathrm{Xi}, \mathrm{i}=1$, 2 and 3 ) by a second-order polynomial equation (Equation ii).

$$
\begin{gathered}
Y=\beta_{0}+\beta_{1} X_{1}+\beta_{2} X_{2}+\beta_{3} X_{3}+\beta_{11} X_{1}^{2}+\beta_{22} X_{2}^{2}+ \\
\beta_{33} X_{3}^{2}+\beta_{12} X_{1} X_{2}+\beta_{13} X_{1 .} X_{3}+\beta_{14} X_{2} X_{3}+
\end{gathered}
$$

The coefficients of the polynomial were represented by $\beta_{0}$ (constant), $\beta_{1}, \beta_{2}, \beta_{3}$ (linear effects); $\beta_{12}, \beta_{13}, \beta_{14}$ (quadratic effects); $\beta_{11}, \beta_{22}, \beta_{33}$ (quadratic effects); and $\varepsilon$ (random error). Data were modelled by multiple regression analysis and the statistical significance of the terms were examined by analysis of variance (ANOVA) for each.

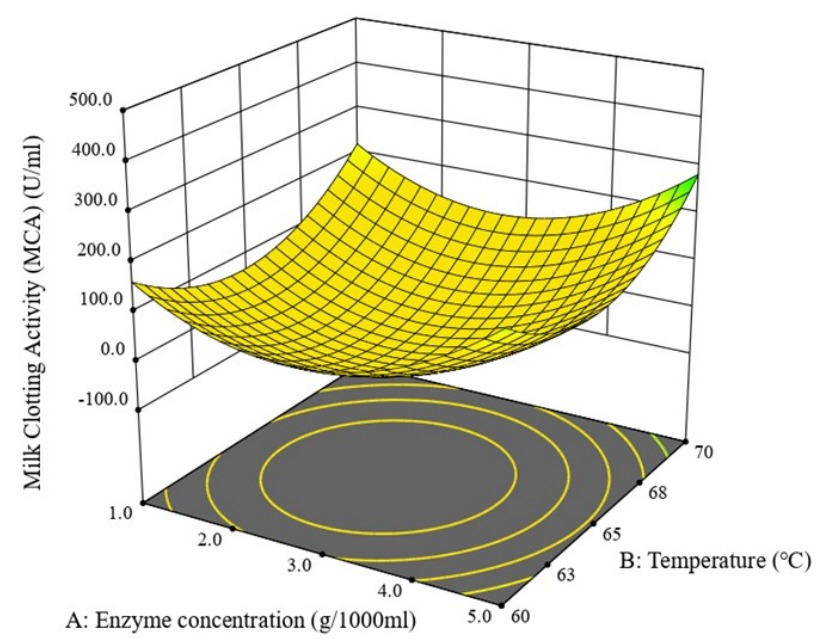

Figure 2 Response surface plot for MCA as a function of temperature of milk and enzyme concentration at $\mathrm{pH}$ 6.5. 


\section{Preparation of soft-unripened cheese}

With a slight modification in the method given by Walstra et al. (2006), soft-unripened cheeses were prepared by using three variations i.e., the cheese prepared using calf rennet was labelled as cheese $\mathrm{A}$, the cheese prepared using dried papaya latex was labelled as cheese B and the cheese prepared using commercial papain was labelled as cheese C.

Briefly, milk having 3.8\% fat and $8.5 \%$ SNF content was heated until it reached the temperature of $75-80^{\circ} \mathrm{C}$ followed by stirring for $1 \mathrm{~min}$. For cheese A, the initial $\mathrm{pH}$ (6.6) of milk was reduced to 5.6 by the addition of $2 \%$ citric acid solution and the enzyme was added at a temperature of $37^{\circ} \mathrm{C}$ for optimum activity of rennet; while for cheeses $\mathrm{B}$ and $\mathrm{C}, \mathrm{pH}(6.5)$ and temperature $\left(70^{\circ} \mathrm{C}\right)$ of the milk were adjusted. The $\mathrm{pH}$ of the milk was adjusted by citric acid solution (2\%). The milk was stirred gently for about 10-15 secs and incubated at $37^{\circ} \mathrm{C}$ for 30 mins.

Table 2

Experimental design setup for soft cheese preparation using RSM/CCRD.

\begin{tabular}{cccc}
\hline Run & $\begin{array}{c}\text { Factor1 } \\
\text { A: Enzyme } \\
\text { concentration } \\
\text { g/1000ml }\end{array}$ & $\begin{array}{c}\text { Factor 2 } \\
\text { B: Temperature }\end{array}$ & $\begin{array}{c}\text { Factor 3 } \\
\text { C: } \mathbf{p H}\end{array}$ \\
\hline 1 & 3.0 & 65 & \\
2 & 5.0 & 60 & 7.3 \\
3 & 1.0 & 60 & 7.0 \\
4 & 1.0 & 60 & 6.0 \\
5 & 3.0 & 73 & 7.0 \\
6 & 6.4 & 65 & 6.5 \\
7 & 5.0 & 70 & 6.5 \\
8 & 3.0 & 57 & 6.0 \\
9 & 1.0 & 70 & 6.5 \\
10 & 3.0 & 65 & 6.0 \\
11 & 5.0 & 60 & 5.7 \\
12 & 5.0 & 70 & 6.0 \\
13 & 0.4 & 65 & 7.0 \\
14 & 1.0 & 70 & 6.5 \\
15 & 3.0 & 65 & 7.0 \\
\hline
\end{tabular}

The curd was then cut by a stainless-steel knife to separate the whey and it was further cooked at $38-42^{\circ} \mathrm{C}$ for $15-20$ mins. The curds were drained using cheese cloth and mixed with $2 \%$ common salt. The cheese was stored in refrigerator at $<5^{\circ} \mathrm{C}$. Similar procedure was followed for cheeses B and $\mathrm{C}$ after determining the optimum conditions by RSM.

\section{Physicochemical analysis of cheese}

1. Fat in cheese: Fat in cheese was determined by AOAC official method 933.05 (2005).

2. Determination of $\mathbf{p H}$ in cheese: $\mathrm{The} \mathrm{pH}$ in cheese was determined according to AOAC official method 981.12 (2005).

3.Protein determination in cheese: Protein content in cheese was determined by the Kjeldahl method as per AOAC 991.20 (2005).
4. Determination of acidity in cheese: The acidity of cheese was determined by titrimetric method as per AOAC 920.124 (2005).

5. Determination of moisture in cheese: Moisture in cheese was determined by the oven-drying method as per AOAC 977.11 (2005).

6. Determination of ash in cheese: The ash content in cheese was determined by dry ashing method as per AOAC 935.42 (2005).

7. Determination of calcium in cheese: Calcium content of the cheese was determined by colorimetric method given by AOAC 991.25 (2005).

8. Theoretical yield and actual yield: Theoretical yield was calculated using Van Slyke yield equation (Equation iii) proposed by Fox et al. (2017).

$$
Y=\frac{(0.93 \times \% \mathrm{M} \mathrm{fat})+(\% \mathrm{M} \text { casein }-0.1) \times 109}{100-\text { moisture in cheese }}
$$

where, $\% \mathrm{M}$ fat $=\%$ fat in milk and $\% \mathrm{M}$ casein $=\%$ casein in milk.

Actual yield was calculated by weighing the curd after pressing. The percentage of cheese yield was calculated as (Equation iv) suggested by Razzaq (2003).

Cheese yield $(\%)=\frac{\text { Weight of cheese }(\mathrm{kg})}{\text { Weight of milk }(\mathrm{kg})} \times 100$

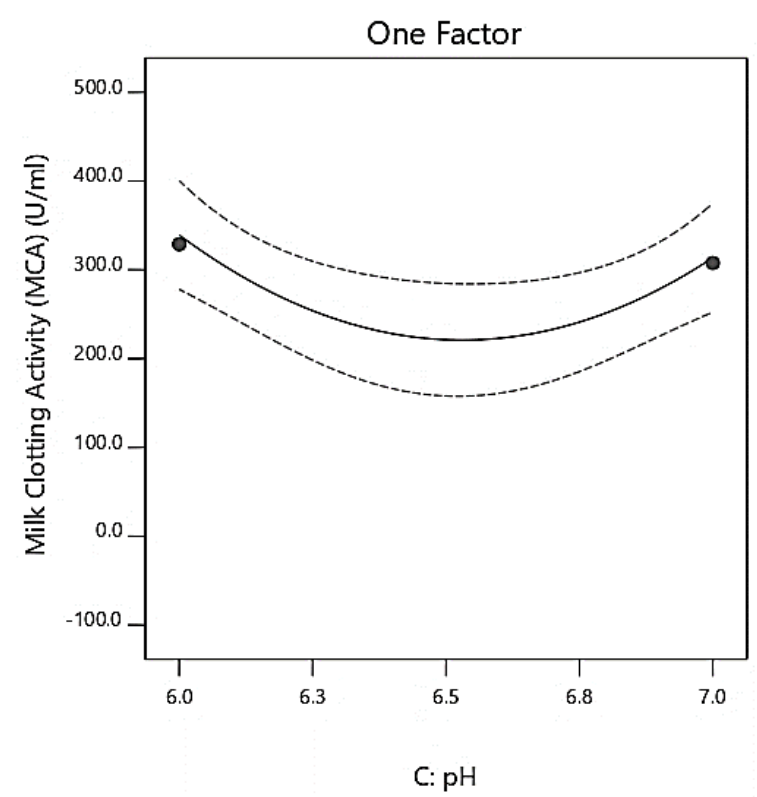

Figure 3 Single factor interaction graph of TOC for individual factor $\mathrm{C}: \mathrm{pH}$.

\section{Sensory evaluation of cheese}

The cheeses were evaluated organoleptically by 10 semitrained panelists, following the recommendations of IDF (1992). The panelists were screened initially based on their sensitivity to recognize basic tastes. Training session was then conducted to define sensory terminologies. Test samples were served as descriptive stimuli for the language development and sensory descriptors for flavour, texture, spreadability, aftertaste and overall acceptance were 
developed. The cheese samples were then presented in a properly ventilated and well-lit laboratory and the panelists evaluated each sample for every attribute using a five-point hedonic scale, with 1 being poor and 5 being the excellent quality.

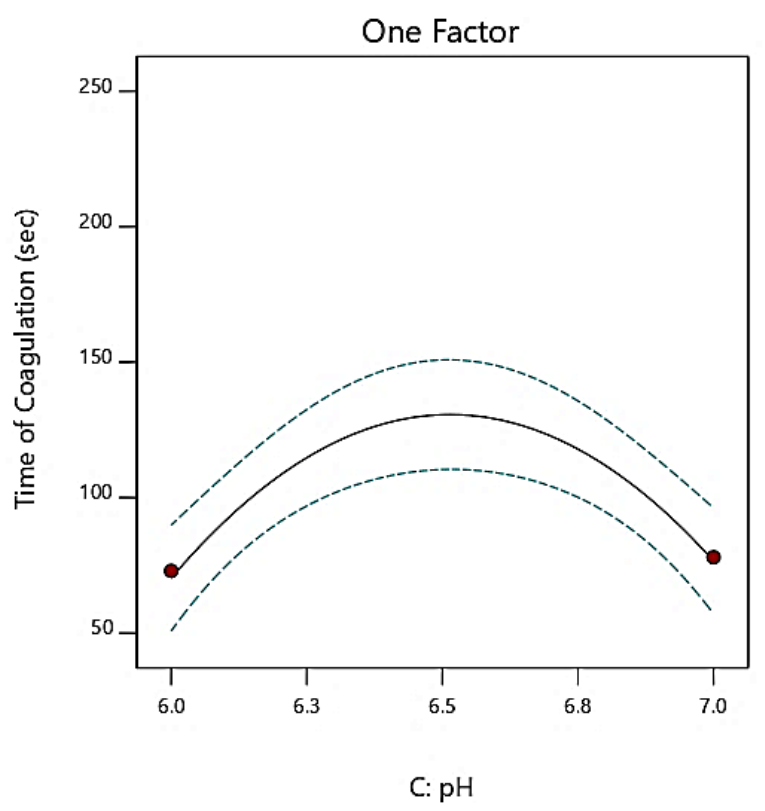

Figure 4 Single factor interaction graph of MCA for individual factor $\mathrm{C}: \mathrm{pH}$

\section{Statistical analysis}

Data were statistically processed by RStudio Version 1.3.959 (R Core Team, Austria). Shapiro-Wilk's test for normality and Levene's test for homogeneity of variance were performed and after confirming the normal distribution, analysis of variance (ANOVA) was carried out. Statistical significance was tested by using Tukey's Honestly Significant Difference (HSD) method at 5\% level of significance.

\section{Results and Discussion}

In this research work, papaya protease was extracted from papaya latex. The impact of enzyme concentration, $\mathrm{pH}$ of milk and temperature of milk on time of coagulation (TOC) and milk coagulating activity (MCA) were analyzed by response surface methodology. The cheeses thus prepared from rennet (A), dried papaya latex (B) and commercial papain (C) were analyzed for physico-chemical properties such as moisture, fat, protein, ash, acidity, $\mathrm{pH}$ and calcium. Various sensory attributes (texture, spreadability, flavor, aftertaste and overall acceptability) of prepared cheeses were analyzed.

\section{Numerical optimization for time of coagulation (TOC) and milk clotting activity (MCA)}

The time of coagulation and milk clotting activity varied from 58-159 $\mathrm{s}$ and 150.9-413.8 units respectively. The following polynomial equation (v) and (vi) represented variation in TOC and MCA within the designed space:

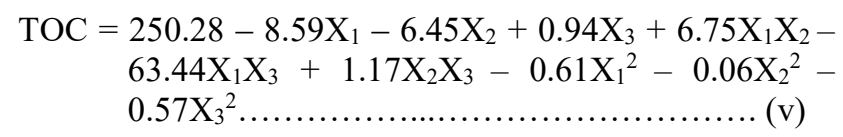

$$
\begin{aligned}
\mathrm{MCA}= & -23.60+33.39 \mathrm{X}_{1}+27.03 \mathrm{X}_{2}-2.81 \mathrm{X}_{3}+2.11 \mathrm{X}_{1} \mathrm{X}_{2} \\
& +4.15 \mathrm{X}_{1} \mathrm{X}_{3}-5.88 \mathrm{X}_{2} \mathrm{X}_{3}+23.29 \mathrm{X}_{1}^{2}+0.19 \mathrm{X}_{2}^{2}+ \\
& 1.31 \mathrm{X}_{3}^{2} \ldots \ldots \ldots \ldots \ldots \ldots \ldots \ldots \ldots \ldots \ldots \ldots \ldots \ldots \ldots \ldots \ldots \ldots \ldots \ldots \ldots \ldots \ldots \ldots \ldots \ldots \ldots \ldots \ldots \ldots
\end{aligned}
$$

where $X_{1}, X_{2}$, and $X_{3}$ are the coded values of enzyme concentration, the temperature of milk and $\mathrm{pH}$ of the milk. $\mathrm{X}_{1}^{2}, \mathrm{X}_{2}^{2}, \mathrm{X}_{3}^{2}, \mathrm{X}_{1} \mathrm{X}_{2}, \mathrm{X}_{1} \mathrm{X}_{3}$ and $\mathrm{X}_{2} \mathrm{X}_{3}$ are model terms.

$$
\mathbf{\$} \text { Theoretical yield (\%) } \quad \text { Actual yield (\%) }
$$

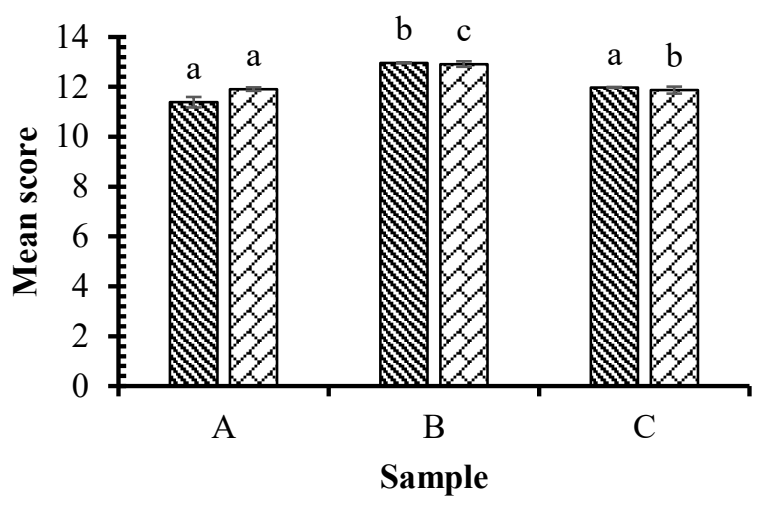

Figure 5 Theoretical and Experimental yield of cream cheeses. All results are expressed as the mean \pm standard deviation $(n=3)$. Means in a single figure with different alphabets are significantly different $(\mathrm{p}<0.05)$.

In the quadratic Equation (v), enzyme concentration $\left(\mathrm{X}_{1}\right)$ and temperature of milk $\left(\mathrm{X}_{2}\right)$ had significant $(\mathrm{p}<0.05)$ negative effect on TOC. But $\mathrm{pH}$ of milk $\left(\mathrm{X}_{3}\right)$ had a nonsignificant $(p>0.05)$ positive effect on TOC. The quadratic terms of enzyme concentration, temperature of milk and $\mathrm{pH}$ of milk had a highly significant $(\mathrm{p}<0.05)$ negative effect on TOC as given in Table 3. The interaction terms of enzyme concentration and temperature of milk $\left(\mathrm{X}_{1} \mathrm{X}_{2}\right)$, and temperature of milk and $\mathrm{pH}$ of milk $\left(\mathrm{X}_{2} \mathrm{X}_{3}\right)$ had a nonsignificant $(\mathrm{p}>0.05)$ positive effect on TOC.

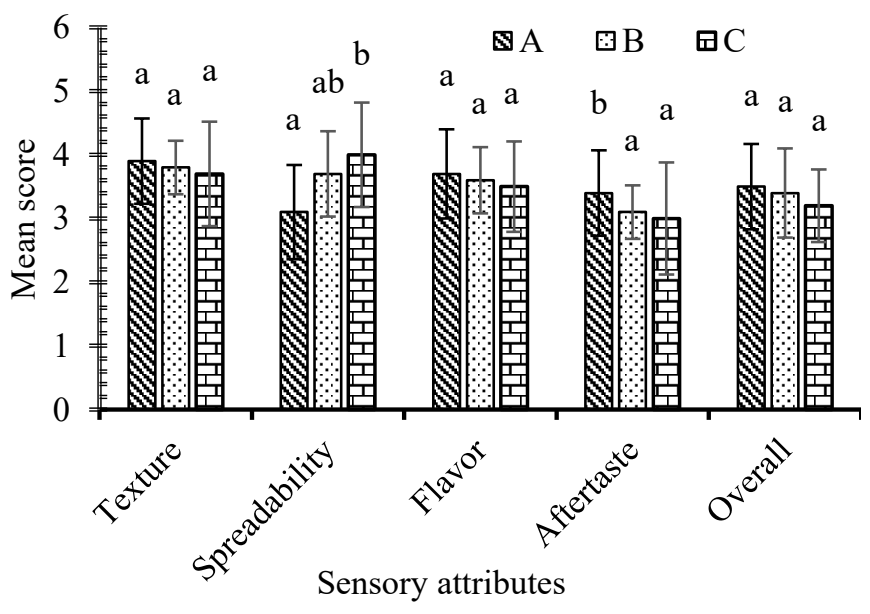

Figure 6 Graphical view of mean sensory scores of cheeses. All results are expressed as the mean \pm standard deviation $(n=10)$. Means in a single parameter with different alphabets on the top of the bars are significantly different $(\mathrm{p}<0.05)$. 
Table 3

Analysis of variance (ANOVA) for response surface quadratic model of time of coagulation.

\begin{tabular}{|c|c|c|c|c|c|c|}
\hline Source & Sum of Squares & df & Mean Square & F-value & p-value & \\
\hline Model & 7864.29 & 9 & 873.81 & 13.59 & 0.0115 & significant \\
\hline $\mathrm{X}_{1}$-Enzyme concentration & 734.84 & 1 & 734.84 & 11.43 & 0.0278 & \\
\hline $\mathrm{X}_{2}$-Temperature & 568.79 & 1 & 568.79 & 8.85 & 0.0410 & \\
\hline $\mathrm{X}_{3}-\mathrm{pH}$ & 12.03 & 1 & 12.03 & 0.1871 & 0.6876 & \\
\hline $\mathrm{X}_{1} \mathrm{X}_{2}$ & 12.50 & 1 & 12.50 & 0.1944 & 0.6820 & \\
\hline $\mathrm{X}_{1} \mathrm{X}_{3}$ & 4.50 & 1 & 4.50 & 0.0700 & 0.8044 & \\
\hline $\mathrm{X}_{2} \mathrm{X}_{3}$ & 18.00 & 1 & 18.00 & 0.2800 & 0.6247 & \\
\hline $\mathrm{X}_{1}^{2}$ & 2816.65 & 1 & 2816.65 & 43.81 & 0.0027 & \\
\hline $\mathrm{X}_{2}^{2}$ & 3898.25 & 1 & 3898.25 & 60.64 & 0.0015 & \\
\hline $\mathrm{X}_{3}^{2}$ & 3518.34 & 1 & 3518.34 & 54.73 & 0.0018 & \\
\hline Residual & 257.14 & 4 & 64.29 & & & \\
\hline Cor Total & 8121.43 & 13 & & & & \\
\hline
\end{tabular}

However, interaction term, enzyme concentration and $\mathrm{pH}$ of milk $\left(\mathrm{X}_{1} \mathrm{X}_{3}\right)$ had a non-significant negative effect $(\mathrm{p}>0.05)$. The significant negative effect of a quadratic term of enzyme concentration, temperature and $\mathrm{pH}$ indicated a convex shaped variation in TOC of the cheese (Figure 1). Similarly, the quadratic Equation (vi) of MCA shows that enzyme concentration $\left(\mathrm{X}_{1}\right)$ and temperature of milk $\left(\mathrm{X}_{2}\right)$ had a significant $(p<0.05)$ positive effect whereas the $\mathrm{pH}$ of milk $\left(\mathrm{X}_{3}\right)$ had a non-significant $(\mathrm{p}>0.05)$ negative effect on MCA.

The quadratic terms of enzyme concentration, temperature of milk and $\mathrm{pH}$ of milk had a highly significant $(\mathrm{p}<0.05)$ positive effect on MCA as given in Table 4. The interaction terms of enzyme concentration and temperature of milk $\left(\mathrm{X}_{1} \mathrm{X}_{2}\right)$, and temperature of milk and $\mathrm{pH}$ of milk $\left(\mathrm{X}_{2} \mathrm{X}_{3}\right)$ had a non-significant $(p>0.05)$ negative effect on MCA. Other interaction terms enzyme concentration and $\mathrm{pH}$ of milk $\left(\mathrm{X}_{1} \mathrm{X}_{3}\right)$ had a non-significant positive effect $(\mathrm{p}>0.05)$. The significant positive effect of enzyme concentration, temperature of milk and $\mathrm{pH}$ of milk led to concave shaped variation in MCA (Figure 2). The $\mathrm{pH}$ of the milk has the important linear effect on the final specific activity of the crude enzyme since enzymatic activity is $\mathrm{pH}$ dependent (Amanu, 2015). The maximum TOC and minimum MCA was observed at $\mathrm{pH} 6.5$ (Figure 3 and Figure 4).

\section{Optimization}

A numerical response optimization technique was applied to determine the optimum combination of enzyme concentration, temperature of milk and $\mathrm{pH}$ of milk for the minimum time of coagulation and maximum milk clotting activity, which is shown in Table 5.

Under the assumptions by Design Expert (version 12.0.3), the optimum operating conditions for minimum time of coagulation and maximum milk clotting activity of enzyme were $1 \mathrm{~g} / 1000 \mathrm{ml}, 6.5$ and $70^{\circ} \mathrm{C}$ respectively, for enzyme concentration, $\mathrm{pH}$ and milk temperature. The responses for these optimum conditions reported MCA of 286.4 units at $83.8 \mathrm{~s}$ of coagulation time. Within the scope of the variables investigated in Central Composite Rotatable Design, additional experiments with different processing conditions were conducted to confirm the adequacy of the model equations. The conditions and the results of the confirmatory experiments are presented in Table 6 .

\section{Physicochemical properties of cheese}

\section{Chemical composition of cheese}

The chemical composition of the cheeses made from rennet (A), dried papaya latex (B) and commercial papain (C) has been shown in Table 7.

The moisture content is in the line with the findings of Rana et al. (2017a) but lower than the findings of Amanu (2015) and higher than that of Rana et al. (2017b). Moisture in 
cheeses made using commercial papain and papaya latex were similar to that of rennet. The fat level was slightly higher than the findings of Rana et al. (2017a) who found fat level to be around $21 \%$ to $24 \%$.

Table 4

Analysis of variance (ANOVA) for response surface quadratic model of milk clotting activity.

\begin{tabular}{|c|c|c|c|c|c|}
\hline Source & $\begin{array}{c}\text { Sum of } \\
\text { squares }\end{array}$ & df & $\begin{array}{c}\text { Mean } \\
\text { Square }\end{array}$ & $\begin{array}{c}\text { F- } \\
\text { value }\end{array}$ & $\begin{array}{c}\text { P- } \\
\text { value }\end{array}$ \\
\hline Model & 56674 & 9 & 6297 & 9.99 & 0.02 \\
\hline $\begin{array}{l}\mathrm{X}_{1} \text {-Enzyme } \\
\text { concentration }\end{array}$ & 11093 & 1 & 11093 & 17.59 & 0.01 \\
\hline $\begin{array}{l}\mathrm{X}_{2^{-}} \\
\text {Temperature }\end{array}$ & 9975 & 1 & 9975 & 15.82 & 0.01 \\
\hline $\mathrm{X}_{3}-\mathrm{pH}$ & 108 & 1 & 108 & 0.170 & 0.70 \\
\hline $\mathrm{X}_{1} \mathrm{X}_{2}$ & 35 & 1 & 35 & 0.056 & 0.82 \\
\hline$X_{1} X_{3}$ & 138 & 1 & 138 & 0.218 & 0.67 \\
\hline$X_{2} X_{3}$ & 277 & 1 & 277 & 0.438 & 0.54 \\
\hline $\mathrm{X}_{1}{ }^{2}$ & 12841 & 1 & 12841 & 20.36 & 0.01 \\
\hline $\mathrm{X}_{2}{ }^{2}$ & 15560 & 1 & 15560 & 24.67 & 0.01 \\
\hline $\mathrm{X}_{3}{ }^{2}$ & 11906 & 1 & 11906 & 18.88 & 0.01 \\
\hline Residual & 2522 & 4 & 631 & & \\
\hline Cor Total & 59197 & 13 & & & \\
\hline
\end{tabular}

The protein contents of all the cheeses are in line with the findings of Rana et al. (2017a) but lower than that found by Rana et al. (2017b). The ash contents of cheese are similar to the findings of Khan \& Masud (2013), who had reported that the ash contents of cheese ranged from 2.50 to $3.20 \%$. The $\mathrm{pH}$ and titratable acidity of cheeses did not coincide with the findings of Rana et al. (2017a).

The $\mathrm{pH}$ and acidity value of cheese $\mathrm{A}$ was significantly different $(\mathrm{p}<0.05)$ than $\mathrm{B}$ and $\mathrm{C}$. This may be due to slight difference in optimum conditions used during cheese preparation. The calcium content of cheeses $\mathrm{A}, \mathrm{B}$ and $\mathrm{C}$ range from $614-628 \mathrm{mg} / 100 \mathrm{~g}$ of cheese. No significant differences $(p>0.05)$ could be found in calcium content of the samples.

\section{Theoretical and Experimental yield}

The theoretical and actual yield of cheeses A, B and C have been shown in Figure 5. Among them the average theoretical yield was found significantly $(\mathrm{p}<0.05)$ more in $\mathrm{B}$. The slight variation in theoretical yield might be due to the final moisture contents in cheese (Melilli et al., 2002). Experimental yield obtained for all cheeses was lower than the findings of Rana et al. (2017a) and this variation would be due to difference in milk composition and processing technique. Experimental yield is lower than the theoretical yield which might be due to loss of fat and casein in whey during cheese making resulting in low casein and/or fat retention (Franceschi et al., 2020).

Table 5

Different constraints for optimization.

\begin{tabular}{lccc}
\hline Name & Goal & $\begin{array}{c}\text { Lower } \\
\text { Limit }\end{array}$ & $\begin{array}{c}\text { Upper } \\
\text { Limit }\end{array}$ \\
\hline $\begin{array}{l}\text { Enzyme concentration } \\
(\mathrm{g} / 1000 \mathrm{ml} \text { milk) }\end{array}$ & Minimize & 0.4 & 6.4 \\
\hline $\begin{array}{l}\text { Temperature of milk } \\
\left({ }^{\circ} \mathrm{C}\right)\end{array}$ & is in range & 60 & 70 \\
\hline $\mathrm{pH}$ of milk & is target & 6 & 7 \\
& 6.5 & & \\
\hline Time of coagulation (s) & Minimize & 58 & 159 \\
& & & \\
\hline $\begin{array}{l}\text { Milk clotting activity } \\
(\mathrm{U} / \mathrm{ml})\end{array}$ & Maximize & 150.9 & 413.8 \\
\hline & & & \\
\hline
\end{tabular}

The higher actual yield in cheese prepared with plant protease may be attributed to the longer coagulation time (Liburdi et al., 2019) resulting in more moisture contents which increased the yield.

\section{Sensory evaluation of cheese}

The results of sensory scores (5-point hedonic scales) of the cheese samples are graphically represented in Figure 6.

The texture scores were not significantly $(\mathrm{p}>0.05)$ different for all cheeses. Since the cheeses were not subjected to ripening, no texture difference could be seen (García et al., 2012). However, cheese $C$ had significantly higher score $(p<0.05)$ for spreadability as compared to cheese A. Although the flavor of cheeses $\mathrm{B}$ and $\mathrm{C}$ might be attributed to the inherent property of the crude papain enzyme, it showed no significant difference $(p>0.05)$ in flavor to that compared with cheese A. Due to trace amount of coagulant used and lack of ripening, very little flavor changes could be seen in soft cheeses (García et al., 2012). Cheese A had significantly lower score $(\mathrm{p}<0.05)$ for spreadability than cheeses B and C. Also, a slight bitter aftertaste was observed in cheeses B and C. Aqueous extracts of Withinia coagulans has also showed a bitter taste in the final product (El-Aziz et al., 2012). 
Table 6

Predicted and actual values of the responses at the optimized condition.

\begin{tabular}{|c|c|c|c|c|c|c|}
\hline \multirow[t]{2}{*}{ Response } & \multicolumn{3}{|c|}{ Conditions } & \multirow{2}{*}{$\begin{array}{c}\text { Predicted } \\
\text { value }\end{array}$} & \multirow{2}{*}{$\begin{array}{c}\text { Mean Observed } \\
\text { value }\end{array}$} & \multirow[t]{2}{*}{ Deviation } \\
\hline & $\begin{array}{c}\text { Enzyme } \\
\text { concentration }\end{array}$ & $\begin{array}{c}\text { Temperature } \\
\text { of milk }\end{array}$ & $\begin{array}{c}\text { pH of } \\
\text { milk }\end{array}$ & & & \\
\hline $\begin{array}{l}\text { Time of coagulation } \\
\text { (TOC) }\end{array}$ & 1 & 70 & 6.5 & 83.84 & 79.33 & 3.19 \\
\hline $\begin{array}{l}\text { Milk clotting activity } \\
\text { (MCA) }\end{array}$ & 1 & 70 & 6.5 & 286.39 & 302.534 & 11.41 \\
\hline
\end{tabular}

This bitterness is associated with accumulation of the bitter peptides that contain more hydrophobic amino acid residues when coagulants from plant sources are used (Singh et al., 2003). Since the overall acceptance accounts for all the parameters of the cheeses including texture, flavor, aftertaste and spreadability and does not overlook other parameters for one. Hence, it can be said that cheeses $\mathrm{A}, \mathrm{B}$ and $\mathrm{C}$ were comparable to each other regarding overall acceptance as non-significant difference $(\mathrm{p}>0.05)$ was recorded among all treatments.

Table 7

Chemical composition of different cheeses samples.

\begin{tabular}{lccc}
\hline Parameters & $\mathbf{A}$ & $\mathbf{B}$ & $\mathbf{C}$ \\
\hline Moisture (\%) & $47.43^{\mathrm{a}}$ & $48.22^{\mathrm{a}}$ & $48.42^{\mathrm{a}}$ \\
& \pm 0.27 & \pm 1.15 & \pm 0.08 \\
\hline Fat (\%) & $28.2^{\mathrm{b}}$ & $27.4^{\mathrm{a}}$ & $27.2^{\mathrm{a}}$ \\
& \pm 0.36 & \pm 0.44 & \pm 0.36 \\
\hline Protein (\%) & $19.87^{\mathrm{a}}$ & $19.2^{\mathrm{a}}$ & $19.09^{\mathrm{a}}$ \\
& \pm 0.58 & \pm 0.15 & \pm 0.25 \\
\hline Ash (\%) & $2.57^{\mathrm{a}}$ & $3.3^{\mathrm{b}}$ & $3.27^{\mathrm{b}}$ \\
& \pm 0.35 & \pm 0.13 & \pm 0.21 \\
\hline $\mathrm{pH}$ & $5.63^{\mathrm{a}}$ & $6.61^{\mathrm{b}}$ & $6.55^{\mathrm{b}}$ \\
& \pm 0.11 & \pm 0.09 & \pm 0.04 \\
\hline Acidity & $0.23^{\mathrm{b}}$ & $0.16^{\mathrm{a}}$ & $0.18^{\mathrm{a}}$ \\
& \pm 0.01 & \pm 0.01 & \pm 0.01 \\
\hline Calcium & $628^{\mathrm{a}}$ & $614.7^{\mathrm{a}}$ & $618.3^{\mathrm{a}}$ \\
(mg/100g) & \pm 7.94 & 6.50 & \pm 5.50 \\
\hline
\end{tabular}

\section{Conclusions}

Optimum time of coagulation (TOC) and milk clotting activity (MCA) were obtained at $\mathrm{pH} 6.5$, temperature $70^{\circ} \mathrm{C}$ and enzyme concentration $1 \mathrm{~g} / 1000 \mathrm{ml}$ milk using papaya protease as coagulant. It was observed that crude papaya protease from papaya latex used for the production of softunripened cheese have comparable physicochemical and sensory attributes to cheese made from rennet. The quality of the cheese made from papaya protease can further be improved by the various process of enzyme purification.

\section{Acknowledgement}

We would like to express our humble gratitude to Central Department of Food Technology and Central Campus of Technology and all the teaching faculty and staffs for their co-operation and support.

\section{Conflict of interest}

The authors declare that they do not have any conflict of interest.

\section{Ethical approval}

The study did not involve any inhumane animal testing.

\section{References}

Amanu, M. (2015). Process optimization of milk coagulant extraction from latex of Carica papaya for production of pre-ripened cheese. Addis Ababa University.

Amri, E. \& Mamboya, F. (2012). Papain, a Plant Enzyme of Biological Importance: A Review. American Journal of Biochemistry and Biotechnology, 8(2), 99104.

AOAC (2005). "Association of Official Analytical Chemists". CRC, Washington.

Ben Amira, A., Besbes, S., Attia, H., and Blecker, C. (2017). Milk-clotting properties of plant rennets and their enzymatic, rheological, and sensory role in cheese making: A review. In International Journal of Food Properties, 20, 76-93.

Berridge, N. J. (1952). An improved method of observing the clotting of milk containing rennin. J. Dairy Sci. 19, 328-329.

Bhagavathy, S. Pushya, K. Gayathridevi, R. Jeniffer, J. (2019). Purification, characterization and application of bromelain from Ananas comosus. 4(5).

Chazzara, S., Sidrach, L., Molina, D. \& Rodriguez, J. N. (2007). Characterization of the milk-clotting properties of extracts from artichoke (Cynara scolymus L.) flowers. Int. Dairy J. 17, 1393-1400.

Derso, A. G., \& Dagnew, G. G. (2019). Isolate and Extract for Milk Clotting Enzymes from the leaves of Moringa Oleifera, Carica Papaya and Mangifera Indica and Use in Cheese Making: The Case of Western Hararage Region, Ethiopia. Journal of Food and Nutrition Research, 7(3), 244-254.

Duarte, A. R., Duarte, D. M. R., Moreira, K. A., Cavalcanti, M. T. H., De Lima-Filho, J. L. \& Porto, A. L. F. (2009). A new vegetable source for milk-clotting enzymes. Braz. Arch. Biol. Technol. 52, 1-9.

El-Aziz, M. A., Mohamed, S. H. S. \& Seleet, F. L. (2012). Production and evaluation of soft cheese fortified with ginger extract as a functional dairy food. Polish $J$. Food Nutr. Sci. 62, 77-83. 
Fox, P. F., Guinee, T. P., Cogan, T. M., \& McSweeney, P. L. H. (2017). Cheese yield. In Fundamentals of cheese science (2nd ed., pp. 279-332). Springer Science + Business Media, Inc. https://doi.org/10.1007/978-14899-7681-9

Franceschi, P., Faccia, M., Malacarne, M., Formaggioni, P., \& Summer, A. (2020). Quantification of cheese yield reduction in manufacturing Parmigiano reggiano from milk with non-compliant somatic cells count. Foods, 9(2). https://doi.org/10.3390/foods9020212

Freitas, C. D. T., Leite, H. B., Oliveira, J. P. B., Amaral, J. L., Egito, A. S., Vairo-cavalli, S., Lobo, M. D. P., Monteiro-moreira, A. C. O., \& Ramos, M. V. (2016). Insights into milkclotting activity of latex peptidases from Calotropis procera and Cryptostegia grandi flora. Food Research International, 87, 50-59.

García, V., Rovira, S., Teruel, R., Boutoial, K., Rodríguez, J., Roa, I., \& López, M. B. (2012). Effect of vegetable coagulant, microbial coagulant and calf rennet on physicochemical, proteolysis, sensory and texture profiles of fresh goats cheese. Dairy Science and Technology, 92(6), 691-707. https://doi.org/10.1007/s13594-012-0086-1

García, V., Rovira, S., Boutoial, K., \& Álvarez, D. (2014). A comparison of the use of thistle (Cynara cardunculus L.) and artichoke (Cynara scolymus L.) aqueous extracts for milk coagulation. Dairy Sci. \& Technol. 95, 197-208. https://doi.org/10.1007/s13594-014-0197-y

Grozdanovic, M. M., Burazer, L., \& Gavrovic-Jankulovic, M. (2013). Kiwifruit (Actinidia deliciosa) extract shows potential as a low-cost andefficient milkclotting agent. International Dairy Journal, 32(1), 4652.

Gupta, V. K., Tuohy, M. G., O’Donovan, A., \& Lohani, M. (2015). Biotechnology of bioactive compounds: sources and applications. John Wiley and Sons, Hoboken.

Hashim, M. M., Mingsheng, D., Iqbal, M. F., \& Xiaohong, C., 2011. Ginger rhizome as a potential source of milk coagulating cysteine protease. Phytochem., 72, 458464.

Hickey, M. (2017). Chapter 30 - Legislation in Relation to Cheese Cheese (Fourth edition) (pp. 757-778). San Diego: Academic Press.

IDF (1992). "Sensory Evaluation of Dairy Products by Scoring ". Brussels. Int. Dairy Federation.

IDF (2007). Determination of total milk-clotting activity of bovine rennet. Int Stand IDF 157. International Dairy Federation, Brussels.

Jacob, M., Jaros, D. and Rohm, H. (2011). Recent advances in milk clotting enzymes. Int. J. Dairy Technol. 64, 1433.

Khan, R. S. \& Masud, T. (2013). Comparison of buffalo cottage cheese made from aqueous extract of Withinia coagulans with commercial calf rennet. Int. J. Dairy Technol. 66(3), 396-401.

Liburdi, K., Boselli, C., Giangolini, G., Amatiste, S., \& Esti, M. (2019). An evaluation of the clotting properties of three plant rennets in the milks of different animal species. Foods, 8(600), 1-12. https://doi.org/10.3390/foods8120600

Mahajan, R. T., \& Badgujar, S. B. (2010). Biological aspects of proteolytic enzymes : A Review. Journal of Pharmacy Research, 3(94), 2048-2068.

Mazorra-Manzano, M. A., Perea-Gutiérrez, T. C., LugoSánchez, M. E., Ramirez-Suarez, J. C., Torres-Llanez, M. J., González-Córdova, A. F., \& Vallejo-Cordoba, B. (2013). Comparison of the milkclotting properties of three plant extracts. Food Chemistry, 141(3), 19021907.

Melilli, C., Lyncht, J. M., Carpino, S., Barbano, D. M., Licitra, G. \& Cappa, A. (2002). An empirical method for prediction of cheese yield. J. Dairy Sci. 85, 26992704.

Nitsawang, S., Hatti-Kaul, R. \& Kanasawud, P. (2006). Purification of papain from Carica papaya latex: Aqueous two phase extraction versus two step salt precipitation. Enz. Microb. Technol. 39(5), 1103-1107.

Pontual, E. V, Carvalho, B. E. A., Bezerra, R. S., Coelho, L. C. B. B., Napoleão, T. H., \& Paiva, P. M. G. (2012). Caseinolytic and milk-clotting activities from Moringa oleifera flowers. Food Chemistry, 135(3), 1848-1854.

Prasetyo, H., Kartawiria, I. S. \& Marpaung, A. M. (2015). Optimization of Papain Enzyme Utilization in NonRennet Cream Cheese Production. Proc. Int. Conference on Innovation, Enterpreneurship and Technology. November. pp. 205-210.

Puig, A., Gil, I. \& Sanchez, O. (2008). Evaluation of drying techniques measuring proteolytic activity of papain obtained from unripe fruit and skin juice. Presented at Indian Biotechnol. Intern. Conference. June. pp. 8-11.

Rana, M. S., Hoque, M. R., Rahman, M. O., Habib, R., \& Siddiki, M. S. R. (2017a). Papaya (Carica papaya) latex- an alternative to rennet for cottage cheese preparation. Journal of Advanced Veterinary and Animal Research, 4(3), 249-254. https://doi.org/10.5455/javar.2017.d218

Rana, M. S., Hoque, M. R., Nahar, T. N., Habib, R. \& Siddiki, M. S. R. (2017b). Preparation of cottage cheese from buffalo milk with different levels of papaya latex. Bangladesh J. Animal Sci. 46(2), 128133.

Razzaq, S. (2003). Preparation of cottage cheese using Sodom Apple (Calotropis procera) latex as a plant rennet. M.Sc. (Hons) Thesis. Arid Agric. Univ., Pakistan.

R Core Team (2020). R: A language and environment for statistical computing. R Foundation for Statistical Computing, Vienna, Austria. URL https://www.Rproject.org/.

Shah, M.A., Mir, S.A., Paray, M.A. (2014). Plant proteases as milk clotting enzymes in cheesemaking: a review. Dairy Sci. Technol. 94(1), 5-16.

Singh, T. K., Drake, M. A. \& Cadwallader, K. R. (2003). Flavor of cheddar cheese: a chemical and sensory perspective. Compr. Rev. Food Sci. Food Safety. 2, 139-162.

Walstra, P., Wouters, J. T. M. \& Geurts, T. J. (2006). Cheese Varieties. In: "Dairy Science and Technology" (2nd ed.). pp. 687-739. CRC Press, Taylor \& Francis Group. 